\title{
Inhibition of Tumor Cell Glutamine Uptake by Isolated Neutrophils
}

\author{
Douglas B. Leam and Edwin L. Thomas \\ Department of Biochemistry, St. Jude Children's Research Hospital, Memphis, Tennessee 38101-0318
}

\begin{abstract}
Antitumor activity of phorbol myristate acetate-(PMA) stimulated neutrophils was measured against CCRF-CEM cells. Neutrophils and tumor cells were incubated $(a)$ as a suspension with continuous mixing to maximize the availability of oxygen or (b) after centrifugation as a pellet to maximize cell-cell contact. The cells were then incubated briefly as a suspension with $\left[{ }^{14}\right.$ Clglutamine under conditions that blocked further damage to the tumor cells. When cells were incubated as a suspension, inhibition of tumor-cell glutamine uptake was mediated by the myeloperoxidase/hydrogen peroxide/chloride system of stimulated neutrophịls. Inhibition was blocked by adding catalase, an inhibitor of myeloperoxidase, or compounds that scavenge hypochlorous acid or chloramines. When cells were incubated as a pellet, a portion of the inhibition could not be blocked in this way, indicating that a nonoxidative mechanism contributed to inhibition. In both systems, inhibition of glutamine uptake was rapid and was obtained at effector-cell/target-cell ratios as low as 0.5:1. This inhibition was obtained under conditions that did not result in ${ }^{51} \mathrm{Cr}$ release from cells labeled with $\left[{ }^{51} \mathrm{Cr}\right]-$ chromate, indicating that inhibition of glutamine uptake measured cytotoxicity rather than cytolysis. ${ }^{51} \mathrm{Cr}$ release was observed only when cells were incubated together for an hour or more as a pellet at high $\mathrm{E} / \mathrm{T}$ ratios. This cytolysis was mediated by the myeloperoxidase system, and a nonoxidative contribution to cytolysis was not observed. The results indicate that stimulated neutrophils are potent antitumor effector cells when cytotoxicity rather than cytolysis is the measure of activity. Because glutamine is required for growth of many tumor cells, inhibition of glutamine uptake may represent a significant tumoristatic or tumoricidal effect.
\end{abstract}

\section{Introduction}

Leukocyte antitumor activities contribute to natural resistance to tumor growth and provide a basis for efforts to treat cancer by immunization or with immunoregulatory substances. Certain activated macrophages and lymphocytes recognize and selectively kill tumor cells. Neutrophils apparently do not recognize tumor cells as targets in the absence of anti-tumor

A portion of the results was presented at the 23rd National Meeting of the Reticuloendothelial Society, 1986, and published in abstract form (1986. J. Leuk. Biol. 40:284a.)

Address reprints to Dr. Edwin L. Thomas, Department of Biochemistry, St. Jude Children's Research Hospital, 332 North Lauderdale, Memphis, TN 38101-0318.

Received for publication 25 November 1987 and in revised form 14 March 1988.

J. Clin. Invest.

(c) The American Society for Clinical Investigation, Inc.

0021-9738/88/09/0789/08 \$2.00

Volume 82, September 1988, 789-796 antibodies, but can kill many different types of cells when appropriately stimulated. For example, contact with opsonized cells stimulates neutrophil secretion of toxic proteins and peptides and the respiratory burst, which produces toxic oxidizing agents. Neutrophil toxins may contribute to antitumor activity when resistance is promoted by immunization against tumor-cell antigens or when tumor cells are damaged in ways that create signals for neutrophil binding and stimulation.

Many studies have examined the toxicity of stimulated neutrophils to tumor cells in vitro (1-12). These studies have concluded that antitumor activity is due to the production of toxic oxidizing agents by the myeloperoxidase (MPO) ${ }^{1} /$ hydro- $^{2}$ gen peroxide $\left(\mathrm{H}_{2} \mathrm{O}_{2}\right)$ /chloride $\left(\mathrm{Cl}^{-}\right)$system, though proteins (13) and peptides (14) isolated from neutrophil secretory granules were also shown to be toxic. High ratios of neutrophils to tumor cells were required fơr detectable toxicity, which raised questions about the physiologic significance of neutrophil antitumor activity.

These studies evaluated antitumor activity by measuring the release of radiolabeled intracellular macromolecules from tumor cells labeled with $\left[{ }^{51} \mathrm{Cr}\right]$ chromate. The ${ }^{51} \mathrm{Cr}$-release method is rapid, simple, and applicable to many different target cells. Only the target cells are labeled, so that results are not complicated by the release of materials from effector cells, and it is not necessary to separate effector and target cells before measuring ${ }^{51} \mathrm{Cr}$ release. However, this method also has important disadvantages. Stimulated leukocytes can ingest or precipitate labeled target cell components, resulting in an underestimate of cell damage. Moreover, ${ }^{51} \mathrm{Cr}$ release measures cytolysis rather than cytotoxicity. This assay may overlook subtle effects on target cell structure, metabolism, and growth that would be important in vivo. Using a physiologic process as the indicator of cytotoxicity might permit studies at effector-cell:target-cell $(\mathrm{E} / \mathrm{T})$ ratios closer to those acheived in vivo. Such an assay might also help to identify the cell functions that are sensitive to leukocyte toxins and important targets for cytotoxic activities.

Glutamine transport and metabolism are physiologic processes that have been well studied in a number of cells and tissues. Glutamine is the predominant amino acid in human plasma (15), and many mammalian cells have a transport system for glutamine (16). Cells of lymphoid origin and certain tissues take up glutamine rapidly and may use glutamine rather than glucose as their major energy source (16-20). Growth of most mammalian cells in vitro requires high levels of glutamine $(21,22)$, although this requirement may be an artifact of the tissue-culture system (23). High rates of glutamine use may be characteristic of tumor cells both in vitro and in vivo (24-26), and experimental cancer therapies have been developed based on depriving tumor cells of glutamine (27-30). Therefore, most tumor cell lines used in studies of

1. Abbreviations used in this paper: AIB, $\alpha$-aminoisobutyric acid; MeAIB, $N$-methyl $\alpha$-aminoisobutyric acid; MPO, myeloperoxidase. 
leukocyte antitumor activity probably express high rates of glutamine uptake and require glutamine for growth. In comparison, neutrophils have very low levels of transport systems for amino acids (31). Glutamine uptake was chosen as an indicator to investigate mechanisms of cytotoxicity of stimulated neutrophils toward CEM tumor cells.

\section{Methods}

$\left[{ }^{51} \mathrm{Cr}\right] \mathrm{Chromate}(1 \mathrm{mCi} / \mathrm{ml})$ and $U-\left[{ }^{14} \mathrm{C}\right]$ glutamine $(20-50 \mathrm{Ci} / \mathrm{mol})$ were purchased from Amersham Corp., Arlington Heights, IL. Amino acids, antioxidants, choline chloride, 4,4'-diaminodiphenyl sulfone (dapsone), and SOD were obtained from Sigma Chemical Co., St. Louis, MO, as were the reagents for spectrophotometric determination of ammonia $\left(\mathrm{NH}_{4}^{+}\right.$) based on $\mathrm{NH}_{4}^{+}$-dependent consumption of $\mathrm{NADH}$ catalyzed by glutamate dehydrogenase in the presence of $\alpha$-ketoglutarate. Catalase was purchased from Boehringer Mannheim Biochemicals, Indianapolis, IN. FCS and RPMI 1640 medium were obtained from Gibco Laboratories, Grand Island, NY. PMA was purchased from Pharmacia Fine Chemicals, Piscataway, NJ. Reagents for chemiluminescent determination of ATP were obtained from Turner Designs, Mountain View, CA. MPO was purified $(32,33)$ from human leukemic leukocytes. Catalase crystals were washed by centrifugation in water and dissolved in a $\mathrm{Cl}^{-}$medium containing $0.14 \mathrm{M} \mathrm{NaCl}$ with

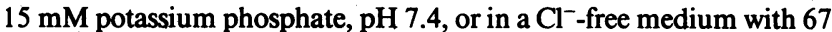
$\mathrm{mM} \mathrm{Na} \mathrm{SO}_{4}$ in place of $\mathrm{NaCl}$. $\mathrm{Na}^{+}$-free media were also prepared in which $0.14 \mathrm{M}$ choline chloride or $\mathrm{LiCl}$ replaced $\mathrm{NaCl}$. Monochloramine $\left(\mathrm{NH}_{2} \mathrm{Cl}\right)$ was prepared by reacting sodium hypochlorite with $\mathrm{NH}_{4}^{+}$in $\mathrm{Cl}^{-}$medium (34).

Cells. Neutrophils were isolated from human blood by densitygradient centrifugation (35). Neutrophil preparations were free of mononuclear cells and erythrocytes, but contained an average of $6 \%$ eosinophils. CCRF-CEM cells (ATCC CCL 119; American Type Culture Collection, Rockville, MD), a line of human lymphoblast tumor cells (36), were cultured as a suspension in RPMI 1640 medium with $10 \%$ FCS and $4 \mathrm{mM}$ glutamine. Cells were harvested by centrifugation and washed in $\mathrm{Cl}^{-}$medium or the other isotonic media. ${ }^{51} \mathrm{Cr}$-labeled cells were prepared by incubating cells at $2 \times 10^{7} / \mathrm{ml}$ with $10 \mathrm{mM}$ glucose and $0.1 \mathrm{mCi} / \mathrm{ml}\left[{ }^{51} \mathrm{Cr}\right]$ chromate for $1 \mathrm{~h}$ at $37^{\circ} \mathrm{C}$. The cells then were washed three times in cold $\mathrm{Cl}^{-}$medium.

Incubations. Neutrophils and CEM cells were combined in $0.5 \mathrm{ml}$ total volume containing cold $\mathrm{Cl}^{-}$or $\mathrm{Cl}^{-}$-free medium with $5 \mathrm{mM}$ glucose, $1 \mathrm{mM} \mathrm{MgSO}_{4}$, and $80 \mathrm{nM}$ PMA added as a 1:1 molar complex with BSA (37). To maximize the availability of $\mathrm{O}_{2}$, suspensions in $15-\mathrm{ml}$ siliconized glass tubes were incubated at $37^{\circ} \mathrm{C}$ with continuous mixing. To maximize cell-cell contact, suspensions in flat-bottomed siliconized glass vials were centrifuged in the cold for $1 \mathrm{~min}$ at $900 \mathrm{~g}$ into a pellet consisting of a cell layer of uniform depth and $1.2 \mathrm{~cm}^{2}$ area, and then incubated at $37^{\circ} \mathrm{C}$ without mixing.

Glutamine uptake. Incubation mixtures were placed on ice, cell pellets were resuspended, and the mixtures were supplemented with $\mathbf{3 0}$ $\mu \mathrm{g} / \mathrm{ml}$ catalase, $0.1 \mathrm{mg} / \mathrm{ml} \mathrm{SOD}, 50 \mu \mathrm{M}$ DTT, $0.5 \mathrm{mM}$ unlabeled glutamine, and $22 \mathrm{nCi} / \mathrm{ml}\left[{ }^{14} \mathrm{C}\right]$ glutamine. The mixtures were incubated for $15 \mathrm{~min}$ at $37^{\circ} \mathrm{C}$, placed on ice, diluted with $3 \mathrm{ml}$ cold medium, and centrifuged $10 \mathrm{~min}$ at $14,000 \mathrm{~g}$ in the cold. Cell pellets were extracted with $0.5 \mathrm{ml}$ of $10 \%$ (wt/vol) sulfosalicylic acid for $5 \mathrm{~min}$ at $100^{\circ} \mathrm{C}$ and then centrifuged. Radioactivity in the extracts was measured in a liquid scintillation spectrometer. Percent inhibition of uptake was calculated as $100(1-(A-C) /(B-C))$, where $A$ and $B$ are uptake with and without neutrophils. $C$ is the radiolabel associated with cells held for 15 min on ice.

${ }^{51} \mathrm{Cr}$ release. Incubation mixtures with ${ }^{51} \mathrm{Cr}$-labeled CEM cells were placed on ice and then centrifuged in the cold. Radioactivity in the supernatant was measured with a gamma spectrometer. When cells were treated with oxidants in the absence of neutrophils, percent specific ${ }^{51} \mathrm{Cr}$ release (6) was calculated as $100(A-B) /(C-B)$, where $A$ is the experimental value, $B$ is spontaneous release from cells incubated without oxidants, and $C$ is label released by cells incubated with $1 \%$ Triton X-100. When cells were incubated with PMA-stimulated neutrophils, percent PMA-dependent specific ${ }^{51} \mathrm{Cr}$ release was calculated by substituting $D$ for $B$, where $D$ is label released with neutrophils but without PMA. Unstimulated neutrophils suppressed the spontaneous release of label from CEM cells, which was $20-30 \%$ of total label.

\section{Results}

Inhibition of uptake. Incubating CEM cells with neutrophils and PMA resulted in a rapid loss of the ability of CEM cells to take up glutamine during a subsequent incubation with $\left[{ }^{14} \mathrm{C}\right]-$ glutamine (Fig. $1 \mathrm{~A}$ ). During the first $20 \mathrm{~min}$, inhibition was greater when the cells were incubated in suspension, but within $30 \mathrm{~min}$, greater inhibition was obtained when the cells were incubated as a pellet. In both systems, strong inhibition was observed within $10 \mathrm{~min}$. After $1 \mathrm{~h}$ of incubation, inhibition was observed at $\mathrm{E} / \mathrm{T}$ ratios as low as 0.5:1 (Fig. 1B). Greater inhibition was obtained at all $\mathrm{E} / \mathrm{T}$ ratios when cells were incubated as a pellet.

Inhibition of CEM cell glutamine uptake required the addition of an agent to stimulate neutrophil secretion and the respiratory burst. In these experiments and those described below, controls were included in which PMA or neutrophils were omitted. Little or no inhibition was observed without PMA, and PMA had no effect on glutamine uptake by CEM cells in the absence of neutrophils.

Stimulation of neutrophils with PMA resulted in cell-cell aggregation, and separating neutrophils and CEM cells from these aggregates was not possible. Therefore, measurements of glutamine uptake were performed using the mixtures of cells. Experiments with neutrophils alone indicated that these cells did not take up glutamine in the presence or absence of PMA, so that all the uptake by cell mixtures was due to the CEM cells.

Antioxidants were added along with the $\left[{ }^{14} \mathrm{C}\right]$ glutamine to prevent oxidation of the $\left[{ }^{14} \mathrm{C}\right]$ glutamine and to prevent further oxidative damage to the CEM cells during the 15-min incubation required for the uptake assay. Catalase was added to eliminate $\mathrm{H}_{2} \mathrm{O}_{2}$, DTT to act as a scavenger for long-lived oxidants such as chloramines (12), and SOD to prevent superoxide $\left(\mathrm{O}_{2}^{-}\right)$-dependent oxidation of DTT (37). Fig. $1 \mathrm{~A}$ shows that this combination of antioxidants was sufficient to block inhibition. There was no inhibition of uptake during the $15-\mathrm{min}$

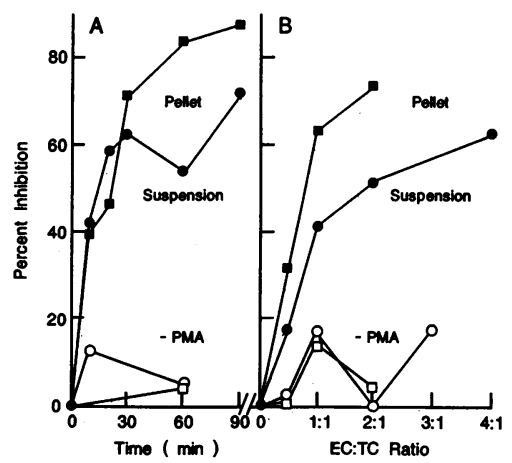

Figure 1. Effect of time and $E / T$ ratio on neutrophil inhibition of CEM cell glutamine uptake. CEM cells $(2$ $\left.\times 10^{6} / \mathrm{ml}\right)$ were incubated with neutrophils as a suspension $(\bullet, 0)$ or as a pellet $(n, \square)$ with PMA (closed symbols) or without PMA (open symbols). $(A)$ Neutrophils at $4 \times 10^{6} / \mathrm{ml}$ $(E / T=2) .(B) 1 \mathrm{~h}$ incubation. Values shown are the mean of duplicate determinations in a typical experiment. 
incubation with $\left[{ }^{14} \mathrm{C}\right]$ glutamine unless the cells were incubated at $37^{\circ} \mathrm{C}$ before the addition of antioxidants and $\left[{ }^{14} \mathrm{C}\right]$ glutamine. As described below, antioxidants did not completely block inhibition when cells were incubated as a pellet. However, the cells were resuspended before incubation with $\left[{ }^{14} \mathrm{C}\right]$ glutamine, and antioxidants were effective under these conditions.

Experiments were performed in which CEM cells and stimulated neutrophils were incubated together, washed by centrifugation in cold buffer, and then incubated with antioxidants and $\left[{ }^{14} \mathrm{C}\right]$ glutamine. Inhibition of uptake did not differ from that seen without washing. These results rule out many possible explanations for the decrease in uptake, such as neutrophil secretion of a glutaminase enzyme, release of unlabeled amino acids that compete with $\left[{ }^{14} \mathrm{C}\right]$ glutamine for transport, acidification of the medium, or accumulation of a reversible inhibitor in the medium. Instead, the results indicate a cytotoxic interaction of neutrophils with CEM cells that inhibited CEM cell functions, and which was not reversed by washing.

Experiments were also performed in which CEM cells were incubated $30 \mathrm{~min}$ with $\left[{ }^{14} \mathrm{C}\right]$ glutamine to load them with radiolabel, washed, and then incubated alone or with neutrophils as a suspension or pellet. Loss of label from the cells was linear with time, and $\sim 15 \%$ of the label was lost in 15 min at $37^{\circ} \mathrm{C}$. Stimulated neutrophils did not cause an increase in the rate of loss of label. Therefore, inhibition of glutamine uptake was not due to nonspecific permeabilization of the CEM cell membrane and loss of the ability to retain $\left[{ }^{14} \mathrm{C}\right]$ glutamine or its metabolites.

Mechanisms of inhibition. Cytotoxicity depended at least in part on the generation of oxidants by the $\mathrm{MPO} / \mathrm{H}_{2} \mathrm{O}_{2} / \mathrm{Cl}^{-}$ system of stimulated neutrophils (Table I). The addition of MPO increased toxicity, indicating that secretion of neutrophil MPO was a limiting factor. SOD increased cytoxicity by promoting the dismutation of $\mathrm{O}_{2}^{-}$to $\mathrm{O}_{2}$ and $\mathrm{H}_{2} \mathrm{O}_{2}$, whereas catalase decreased toxicity by promoting the dismutation of $\mathrm{H}_{2} \mathrm{O}_{2}$ to $\mathrm{O}_{2}$ and water. Cytotoxicity was also decreased by omitting

Table I. Inhibition of CEM Cell Glutamine Uptake by Stimulated Neutrophils

\begin{tabular}{ccc}
\hline & \multicolumn{2}{c}{ Percent inhibition of uptake } \\
\cline { 2 - 3 } & Suspension & Pellet \\
\hline Complete & $51 \pm 9(9)^{*}$ & $75 \pm 10(7)$ \\
+ MPO & $77 \pm 14(8)$ & $91 \pm 9(3)$ \\
+ SOD & $61 \pm 4(4)$ & $86 \pm 6(3)$ \\
+ Catalase & $13 \pm 11(7)$ & $51 \pm 2(3)$ \\
- Cl- & $13 \pm 12(4)$ & $55 \pm 3(2)$ \\
+ Dapsone & $8 \pm 10(4)$ & $58 \pm 13(3)$ \\
+ Taurine & $16 \pm 10(4)$ & $57 \pm 7(3)$ \\
+ Hypotaurine & $16 \pm 13(5)$ & $51 \pm 9(5)$ \\
+ Thiodipropionate & $14 \pm 8(3)$ & $53 \pm 8(3)$ \\
\hline
\end{tabular}

The complete system consisted of neutrophils $\left(4 \times 10^{6} / \mathrm{ml}\right)$ and CEM cells $\left(2 \times 10^{6} / \mathrm{ml}\right)$ incubated with PMA for $1 \mathrm{~h}$ at $37^{\circ} \mathrm{C}$ as a suspension or a pellet. When added, MPO was $50 \mathrm{nM}(6 \mu \mathrm{g} / \mathrm{ml})$, SOD was $50 \mu \mathrm{g} / \mathrm{ml}$, catalase was $30 \mu \mathrm{g} / \mathrm{ml}$, dapsone was $0.1 \mathrm{mM}$, and taurine, hypotaurine, or thiodipropionate was $1 \mathrm{mM}$.

* Mean \pm SD from the number of experiments in parentheses. Duplicate determinations were performed in each experiment.
$\mathrm{Cl}^{-}$from the medium or by adding dapsone (38) to inhibit MPO-catalyzed oxidation of $\mathrm{Cl}^{-}$.

Cytotoxicity was also decreased by adding agents that detoxify oxidants produced by the $\mathrm{MPO} / \mathrm{H}_{2} \mathrm{O}_{2} / \mathrm{Cl}^{-}$system. The amine compound taurine, ${ }^{-} \mathrm{SO}_{3} \mathrm{CH}_{2} \mathrm{CH}_{2} \mathrm{NH}_{3}^{+}$, reacts with hypochlorous acid $(\mathrm{HOCl})$, monochloramine $\left(\mathrm{NH}_{2} \mathrm{Cl}\right)$, and dichloramine derivatives $\left(\mathrm{RNCl}_{2}\right)$ to yield taurine-monochloramine, which is a relatively nontoxic oxidant (12, 39-42). Hypotaurine, ${ }^{-} \mathrm{SO}_{2} \mathrm{CH}_{2} \mathrm{CH}_{2} \mathrm{NH}_{3}^{+}$, contains an amino group like taurine and also a sulfinate group that reduces the oxidized chlorine moieties of $\mathrm{HOCl}$ and chloramines to $\mathrm{Cl}^{-}$(34). Thiodipropionate, $\mathrm{S}\left(\mathrm{CH}_{2} \mathrm{CH}_{2} \mathrm{CO}_{2}^{-}\right)_{2}$, contains a thioether group like that of methionine, which has been used in many studies to block toxicity of the MPO system. Thioethers also reduce oxidized chlorine moieties to $\mathrm{Cl}^{-}(34,43)$.

Taurine, hypotaurine, or thiodipropionate at $0.1 \mathrm{mM}$ did not react with $10 \mathrm{mM} \mathrm{H}_{2} \mathrm{O}_{2}$ during a 1 -h incubation at $37^{\circ} \mathrm{C}$. Nevertheless, these compounds were as effective as catalase in blocking toxicity, indicating that toxicity was mediated by the MPO system and that $\mathrm{H}_{2} \mathrm{O}_{2}$ did not contribute directly to toxicity. Adding $3 \mathrm{mM} \mathrm{H}_{2} \mathrm{O}_{2}$ to $\mathrm{CEM}$ cells and incubating for $1 \mathrm{~h}$ at $37^{\circ} \mathrm{C}$ did not inhibit glutamine uptake, indicating that these cells were highly resistant to the toxicity of $\mathrm{H}_{2} \mathrm{O}_{2}$.

Thiodipropionate and hypotaurine have advantages as agents for blocking cytotoxicity in this and other studies. Unlike taurine, they inhibit the accumulation of long-lived oxidants such as chloramines $(34,43)$. In addition, these compounds did not inhibit neutrophil $\mathrm{O}_{2}$ uptake, interfere with measurements of neutrophil $\mathrm{O}_{2}^{-}$or $\mathrm{H}_{2} \mathrm{O}_{2}$ production, or inhibit CEM cell glutamine uptake. Therefore, the compounds and their oxidation products were nontoxic and did not interfere in assays for neutrophil or CEM cell functions. Thiodipropionate is not a close structural analogue of amino acids and would not be expected to inhibit glutamine uptake. Hypotaurine is oxidized to taurine, which is taken up by a transport system specific for $\beta$-amino acids (16). Taurine does not inhibit uptake of $\alpha$-amino acids such as glutamine. In comparison, methionine competes with other $\alpha$-amino acids for transport, and oxidized forms of methionine are toxic $(44,45)$.

Ammonia $\left(\mathrm{NH}_{4}^{+}\right)$increases the toxicity of the MPO system to target cells such as bacteria (39) and erythrocytes (46), as well as to neutrophils (40). The reaction of $\mathrm{NH}_{4}^{+}$with $\mathrm{HOCl}$ produces the highly toxic oxidizing agent $\mathrm{NH}_{2} \mathrm{Cl}$. However, $\mathrm{NH}_{4}^{+}$at concentrations up to $1 \mathrm{mM}$ had little effect on neutrophil inhibition of CEM cell glutamine uptake, and had a small protective effect at higher concentrations (Fig. 2). This observation may indicate that sufficient $\mathrm{NH}_{4}^{+}$was present for optimal $\mathrm{NH}_{2} \mathrm{Cl}$ production in the absence of added $\mathrm{NH}_{4}^{+}$. As described below, CEM cells released large amounts of $\mathrm{NH}_{4}^{+}$into the medium, and neutrophils also release $\mathrm{NH}_{4}^{+}(12)$. High concentrations of added taurine were required to block cytotoxicity (Fig. 2), indicating that taurine was competing with a high endogenous concentration of $\mathrm{NH}_{4}^{+}$.

Results in Table I indicate that cytotoxicity was due primarily to the MPO system when the cells were incubated as a suspension. On the other hand, agents that almost completely blocked cytotoxicity in suspension were only partly effective when the cells were incubated as a pellet. Each of the agents lowered toxicity to about the same level. These results suggest that part of the higher level of toxicity obtained in the pellet system was due to an additional nonoxidative mechanism that 


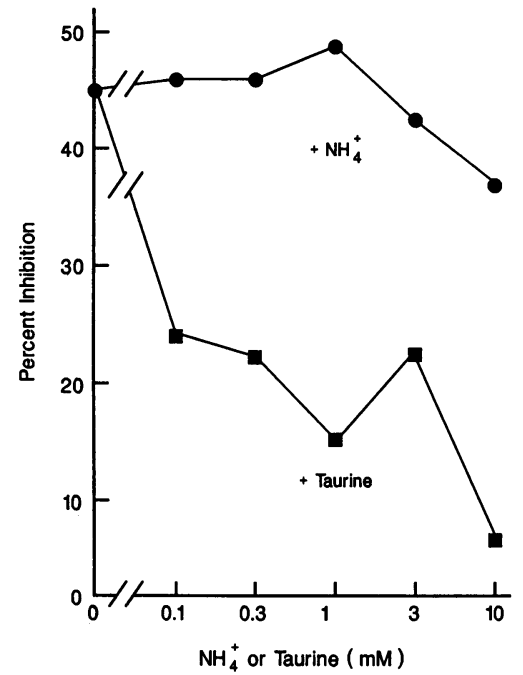

Figure 2. Effect of $\mathrm{NH}_{4}^{+}$ and taurine on neutrophil inhibition of CEM cell glutamine uptake. Neutrophils $(4 \times$ $\left.10^{6} / \mathrm{ml}\right)$, CEM cells $(2$ $\times 10^{6} / \mathrm{ml}$ ), and PMA were incubated $1 \mathrm{~h}$ as a suspension with $\mathrm{NH}_{4}^{+}$ (๑) or taurine (ø). was much less effective when cells were incubated in suspension.

Comparison of cytotoxic and cytolytic activities. CEM cells were labeled with $\left[{ }^{51} \mathrm{Cr}\right]$ chromate and incubated with neutrophils under the same conditions that resulted in inhibition of glutamine uptake. Whereas inhibition of uptake was rapid and was observed when cells were incubated as a suspension or a pellet, ${ }^{51} \mathrm{Cr}$ release was observed only in prolonged incubations and only when cells were incubated as a pellet. Moreover, the amount of ${ }^{51} \mathrm{Cr}$ release was small. Therefore, loss of the ability to take up glutamine was not the result of CEM cell lysis.

Fig. $3 \mathrm{~A}$ shows that only $33 \%{ }^{51} \mathrm{Cr}$ release was obtained during incubations of up to $2 \mathrm{~h}$ with cells in a pellet. The highest release was obtained at $\mathrm{E} / \mathrm{T}$ ratios of $2: 1$ to $4: 1$. In parallel experiments, $<20 \%{ }^{51} \mathrm{Cr}$ release was obtained when cells were incubated in suspension. Fig. $3 A$ also shows that negative values were obtained at high $\mathrm{E} / \mathrm{T}$ ratios. That is, ${ }^{51} \mathrm{Cr}$ release was lower with PMA than without PMA, and both values were lower than the spontaneous release observed in the absence of neutrophils. These results suggest that neutrophils absorbed, precipitated, or phagocytized labeled cell components.

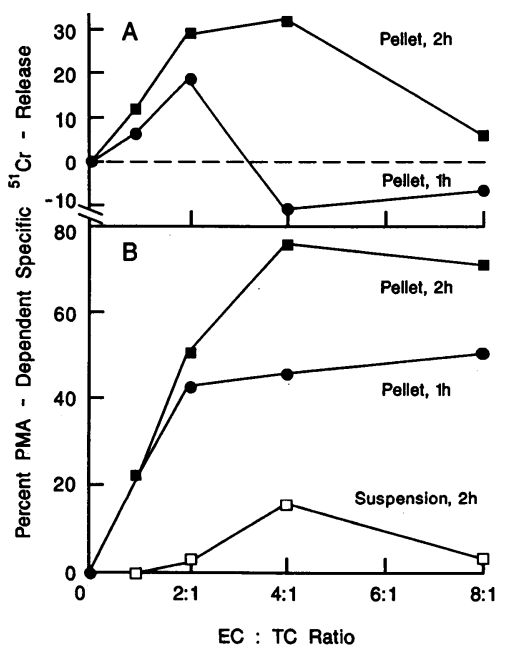

Figure 3. Effect of cell density and $E / T$ ratio on ${ }^{51} \mathrm{Cr}$ release. ${ }^{51} \mathrm{Cr}$-labeled CEM cells at $(A)$ $2 \times 10^{6} / \mathrm{ml}$ or $(B) 5$ $\times 10^{5} / \mathrm{ml}$ were incubated with neutrophils and PMA for $1 \mathrm{~h}(\bullet)$ or $2 \mathrm{~h} \mathrm{(}(\mathbf{)})$ as a pellet or for $2 \mathrm{~h}$ as a suspension (口).
Table II. Effect of MPO and Antioxidants on ${ }^{5 I} \mathrm{Cr}$ Release

\begin{tabular}{cc}
\hline & $\begin{array}{c}\text { Percent PMA-dependent } \\
\text { specific }{ }^{\text {s1 }} \text { Cr release }\end{array}$ \\
\hline Complete (pellet) & $50 \pm 12(5)^{*}$ \\
+ MPO & $70 \pm 10(5)$ \\
+ SOD & $45 \pm 17(5)$ \\
+ Catalase & $10 \pm 10(5)$ \\
+ Taurine & $7 \pm 10(5)$ \\
+ Hypotaurine & $14 \pm 13(4)$ \\
+ Thiodipropionate & $11 \pm 10(4)$ \\
\hline
\end{tabular}

The complete system consisted of neutrophils $\left(1 \times 10^{6} / \mathrm{ml}\right)$ and ${ }^{51} \mathrm{Cr}$ labeled CEM cells $\left(5 \times 10^{5} / \mathrm{ml}\right)$ with PMA incubated $2 \mathrm{~h}$ at $37^{\circ} \mathrm{C}$ as a pellet. When added, MPO was $50 \mathrm{nM}$, SOD was $50 \mu \mathrm{g} / \mathrm{ml}$, catalase was $30 \mu \mathrm{g} / \mathrm{ml}$, and taurine, hypotaurine, or thiodipropionate was 10 mM.

* Mean \pm SD from the number of experiments in parentheses. Duplicate determinations were performed in each experiment.

High levels of ${ }^{51} \mathrm{Cr}$ release similar to those reported in other studies (7) were obtained by adopting conditions used in those studies. This change in conditions consisted of lowering the number of labeled CEM cells fourfold to $5 \times 10^{5} / \mathrm{ml}$ and lowering the numbers of neutrophils to maintain the same $E / T$ ratios. Fig. $3 \mathrm{~B}$ shows that ${ }^{51} \mathrm{Cr}$ release of $50 \%$ or higher was obtained when cells were incubated as a pellet for $1 \mathrm{~h}$ with an $\mathrm{E} / \mathrm{C}$ ratio of $8: 1$, or for $2 \mathrm{~h}$ with ratios of $4: 1$ or higher. Only a low level of ${ }^{51} \mathrm{Cr}$ release was obtained in $2 \mathrm{~h}$ when cells were incubated in suspension. These results confirm reports that prolonged incubations, high $\mathrm{E} / \mathrm{T}$ ratios, and incubation as a pellet are required for extensive cytolysis.

As described above, a nonoxidative cytotoxic mechanism was observed when cells were incubated as a pellet but not as a suspension. Because ${ }^{51} \mathrm{Cr}$ release was much higher when cells were incubated as a pellet, it might be expected that ${ }^{51} \mathrm{Cr}$ release was due to the nonoxidative mechanism. However, results in Table II confirm reports that ${ }^{51} \mathrm{Cr}$ release in the pellet system requires production of oxidants by the MPO system. Cytolysis was increased by adding MPO and blocked by catalase or compounds that detoxify oxidants produced by the MPO system. SOD did not have a significant effect.

Fig. 4 shows results of adding $\mathrm{NH}_{2} \mathrm{Cl}$ to $\mathrm{CEM}$ cells in the absence of neutrophils. Small amounts of $\mathrm{NH}_{2} \mathrm{Cl}$ inhibited glutamine uptake, and larger amounts caused lysis. Inhibition of uptake was nearly complete at concentrations that did not

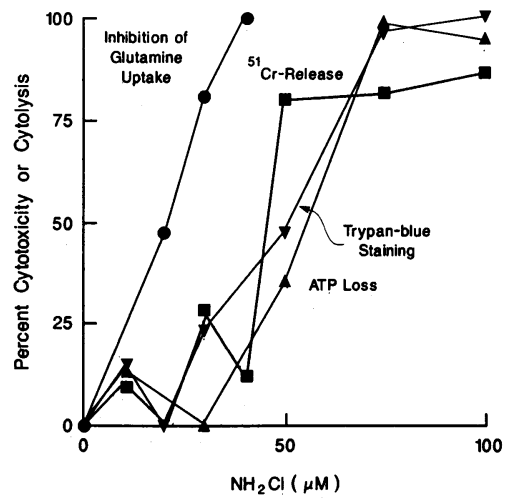

Figure 4. Effect of $\mathrm{NH}_{2} \mathrm{Cl}$ on CEM cells. $\mathrm{NH}_{2} \mathrm{Cl}$ was added to CEM cells $\left(1 \times 10^{6} / \mathrm{ml}\right)$ at the start of a $1-\mathrm{h}$ incubation as a suspension, and then $\left[{ }^{14} \mathrm{C}\right]-$ glutamine uptake (•), ${ }^{51} \mathrm{Cr}$ release (a), trypan blue staining ( $\boldsymbol{\nabla})$, and loss of ATP ( $\Delta)$ were measured. 
cause lysis. Similar results were obtained by adding $\mathrm{HOCl}$ rather than $\mathrm{NH}_{2} \mathrm{Cl}$ (not shown). Differences in the activities of these two oxidants were smaller than those observed with other cells as targets (46). The $\mathrm{NH}_{4}^{+}$released by CEM cells may have converted most of the $\mathrm{HOCl}$ to $\mathrm{NH}_{2} \mathrm{Cl}$, so that the cells were exposed to $\mathrm{NH}_{2} \mathrm{Cl}$ regardless of whether $\mathrm{HOCl}$ or $\mathrm{NH}_{2} \mathrm{Cl}$ was added.

Fig. 4 also shows that similar results were obtained by measuring ${ }^{51} \mathrm{Cr}$ release, staining with trypan blue, or loss of cell ATP as indicators of cell damage. Therefore, ${ }^{51} \mathrm{Cr}$ release did not underestimate the number of dead or lysed cells. Moreover, inhibition of ATP synthesis or depletion of ATP did not account for inhibition of glutamine uptake. The results indicate that oxidants produced by the MPO system had both cytotoxic and cytolytic activities toward CEM cells and that inhibition of glutamine uptake was more sensitive than other indicators of cell injury.

Glutamine uptake. CEM cell glutamine uptake was characterized to determine the probable basis for inhibition. Uptake of label from $0.5 \mathrm{mM}\left[{ }^{14} \mathrm{C}\right]$ glutamine was rapid and linear with time for at least 8 min (Fig. $5 \mathrm{~A}$ ). About $5 \%$ of the label was taken up in $15 \mathrm{~min}$ and $8 \%$ was taken up in $1 \mathrm{~h}$. Total uptake consisted of a saturable, temperature-dependent transport process with an apparent $K_{\mathrm{m}}$ of $0.33 \mathrm{mM}$ and $V_{\max }$ of $2.7 \mu \mathrm{M} / \mathrm{min}$ plus a nonsaturable, temperature-independent binding or diffusion process. In all experiments, values for uptake at $37^{\circ} \mathrm{C}$ were corrected by subtracting the nonsaturable process measured at $4^{\circ} \mathrm{C}$, as shown in Fig. $5 \mathrm{~B}$. Stimulated neutrophils had no effect on the nonsaturable process. Incubation with $0.5 \mathrm{mM}$ $\left[{ }^{14} \mathrm{C}\right]$ glutamine for $15 \mathrm{~min}$ at $37^{\circ} \mathrm{C}$ was chosen as the standard conditions for uptake assays. Under these conditions, the rate of uptake was about equal to the initial rate, the nonsaturable portion was low relative to total uptake, and the amount taken up did not significantly change the extracellular concentration.

All of the label taken up was acid soluble, indicating that glutamine was not used in protein synthesis. Instead, glutamine was rapidly metabolized, as indicated by release of $\mathrm{NH}_{4}^{+}$ into the medium (Fig. 6). Glutamine-dependent $\mathrm{NH}_{4}^{+}$release

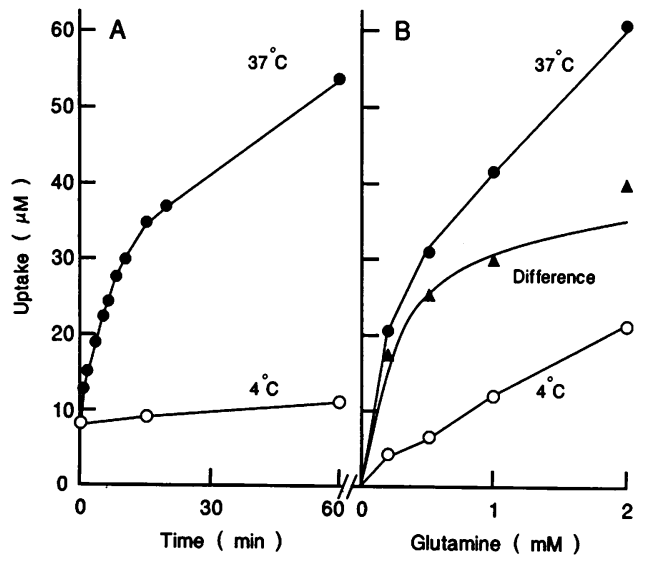

Figure 5. Effect of time and glutamine concentration on CEM cell glutamine uptake. $(A)$ CEM cells $\left(2 \times 10^{6} / \mathrm{ml}\right)$ were incubated with $0.5 \mathrm{mM}\left[{ }^{14} \mathrm{C}\right]$ glutamine and $5 \mathrm{mM}$ glucose at $37^{\circ} \mathrm{C}(\bullet)$ or $4^{\circ} \mathrm{C}(0)$.

(B) CEM cells $\left(2 \times 10^{6} / \mathrm{ml}\right)$ were incubated with $\left[{ }^{14} \mathrm{C}\right]$ glutamine for $15 \mathrm{~min}$ at $37^{\circ} \mathrm{C}(\bullet)$ or $4^{\circ} \mathrm{C}(\mathrm{O})$, and the difference between values at $37^{\circ} \mathrm{C}$ and $4^{\circ} \mathrm{C}$ was plotted $(\triangle)$. The curve drawn through the points was calculated assuming a $K_{\mathrm{m}}$ of $0.33 \mathrm{mM}$ and $V_{\max }$ of $2.7 \mu \mathrm{M} / \mathrm{min}$.

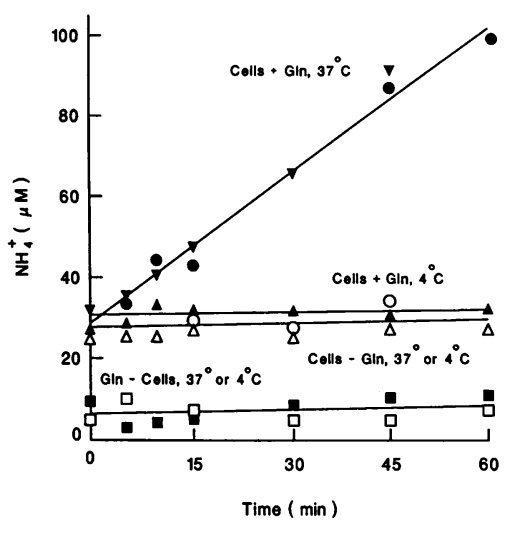

Figure 6. $\mathrm{NH}_{4}^{+}$release. CEM cells were incubated at $37^{\circ} \mathrm{C}$ with glutamine (Gln) and glucose (๑), glutamine alone (v), or glucose alone ( () . Cells were also held at $4^{\circ} \mathrm{C}$ with (o) or without glutamine $(\Delta)$. Glutamine was also incubated at $37^{\circ} \mathrm{C}(\square)$ or held at $4^{\circ} \mathrm{C}$ (口) without cells. When added, cells were 2 $\times 10^{6} / \mathrm{ml}$, glutamine was $0.5 \mathrm{mM}$, and glucose was $5 \mathrm{mM}$. required incubation at $37^{\circ} \mathrm{C}$, was linear with time, and had a concentration dependence similar to that of glutamine uptake $\left(K_{\mathrm{m}}=0.5 \mathrm{mM}, V_{\max }=1.6 \mu \mathrm{M} / \mathrm{min}\right)$. In the first $15 \mathrm{~min}$, about one $\mathrm{NH}_{4}^{+}$was released per glutamine taken up. Therefore, glutamine was rapidly deaminated to glutamate or a mixture of glutamate and $\alpha$-ketoglutarate, and $50 \%$ or less of the label in the cells was in the form of $\left[{ }^{14} \mathrm{C}\right]$ glutamine.

Although glutamine was rapidly metabolized, the results indicate that the amount of label in the cells was about equal to the amount taken up. If a large part of the $\left[{ }^{14} \mathrm{C}\right]$ glutamine taken up was converted to labeled products that were released into the medium, then $\mathrm{NH}_{4}^{+}$release would be much greater than the amount of labeled products remaining in the cell. Other experiments confirmed this observation in that conversion of $\left[{ }^{14} \mathrm{C}\right]$ glutamine to volatile products, including ${ }^{14} \mathrm{CO}_{2}$, was undetectable at $15 \mathrm{~min}$ and only $3 \%$ at $1 \mathrm{~h}$.

Fig. 6 also shows that CEM cells released substantial amounts of $\mathrm{NH}_{4}^{+}$into the medium before the incubations. $\mathrm{NH}_{4}^{+}$release was complete during the 15-30-min period in which the cells were at $4^{\circ} \mathrm{C}$ before the start of the incubations. The cells were thoroughly washed, and $\mathrm{NH}_{4}^{+}$in the incubation mixtures was not due to contamination by $\mathrm{NH}_{4}^{+}$from the growth medium. Fig. 6 also shows that the amount of $\mathrm{NH}_{4}^{+}$ added as a contaminant in the glutamine was $<1 \%$ of the amount of glutamine. Total glutamine decomposition measured as $\mathrm{NH}_{4}^{+}$release in the absence of CEM cells was $<2 \%$ at the end of $1 \mathrm{~h}$.

The presence or absence of glucose had no effect on glutamine uptake or glutamine-dependent $\mathrm{NH}_{4}^{+}$release. Therefore, glucose was not required as an energy source for glutamine uptake, and glucose did not inhibit glutamine uptake or metabolism by competing with glutamine as an energy source.

Preincubating the cells for $1 \mathrm{~h}$ at $37^{\circ} \mathrm{C}$ with or without glucose had no effect on glutamine uptake during a subsequent incubation with $0.5 \mathrm{mM}\left[{ }^{14} \mathrm{C}\right]$ glutamine. Similarly, preincubating for $1 \mathrm{~h}$ with unlabeled glutamine at concentrations up to $20 \mathrm{mM}$, and subsequent washing had no effect on $\left[{ }^{14} \mathrm{C}\right]-$ glutamine uptake. Therefore, the rate of uptake was a stable parameter and did not respond rapidly to the presence or absence of energy sources. Nevertheless, glutamine uptake appeared energy dependent. Preincubating for $1 \mathrm{~h}$ at $37^{\circ} \mathrm{C}$ with glucose and $10 \mathrm{mM}$ cyanide lowered uptake to $9 \%$ of control. Other inhibitors were less effective. Preincubating for $1 \mathrm{~h}$ at $37^{\circ} \mathrm{C}$ with glucose and $10 \mathrm{mM}$ fluoride, arsenate, or azide, or 
with 2-deoxyglucose in the absence of glucose, lowered uptake to $91,68,57$, or $69 \%$ of control. CEM cells were quite resistant to all the inhibitors. Preincubations of $1 \mathrm{~h}$ or more with inhibitor concentrations $>1 \mathrm{mM}$ were required for inhibition of glutamine uptake. There was no inhibition of uptake when metabolic inhibitors were added with $\left[{ }^{14} \mathrm{C}\right]$ glutamine at the start of a 15-min incubation.

Competition between glutamine and other amino acids for uptake was examined to define the transport system(s) responsible for uptake. Glutamate had little effect, indicating that extracellular deamination of glutamine and transport of glutamate did not account for uptake. Neutral amino acids such as glutamine are transported into mammalian cells by systems with broad, overlapping specificities and differing ionic requirements. The $A$ and $A S C$ systems are found in most tissue cells and differ most clearly in their ability to transport $N$ methyl derivatives of amino acids. $N$-Methyl $\alpha$-aminoisobutyric acid is a model substrate for the $A$ transport system, whereas $\alpha$-aminoisobutyric acid is taken up by both the $A$ and $A S C$ systems $(47,48)$. Neither is taken up by the $L$ system (49), which is also widely distributed. MeAIB and AIB inhibited glutamine uptake by 26 and $64 \%$, indicating that $\sim 26 \%$ of uptake was by the $A$ system and $38 \%$ by the $A S C$ system (Table III). The observation that $\sim 64 \%$ of uptake was due to the $\mathrm{Na}^{+}$-dependent $A$ and $A S C$ systems was confirmed by replacing $\mathrm{Na}^{+}$with $\mathrm{Li}^{+}$or the choline cation. The $\mathrm{Na}^{+}$-independent $L$ system accounted for the remaining uptake. Leucine and serine were about equally effective as inhibitors. Leucine competes more effectively than serine for uptake by the $L$ system, whereas serine competes more effectively than leucine for uptake by the $A$ and $A S C$ systems.

Histidine competes with glutamine for uptake by the $\mathrm{Na}^{+}$dependent $N$ system, which is the major transport system for glutamine in hepatocytes $(50,51)$. However, the results did not indicate a contribution by the $N$ system to CEM cell glutamine uptake. The cation dependence of the $N$ system differs from that of $A$ and $A S C$ in that $\mathrm{Li}^{+}$substitutes for $\mathrm{Na}^{+}$as a cosubstrate for the $N$ system. Uptake in $\mathrm{Li}^{+}$medium was no higher than in the choline medium, indicating that there was no $\mathrm{Li}^{+}$dependent uptake by the $N$ system. Histidine inhibited uptake, but most of this inhibition was due to competition for uptake by the $L$ system. The results indicate that the $A, A S C$, and $L$ systems made major contributions to glutamine uptake and that about two-thirds of the uptake was $\mathrm{Na}^{+}$dependent.

Table III. Effect of Amino Acid Competition and Cation Substitution on CEM Cell Glutamine Uptake

\begin{tabular}{lccc}
\hline & \multicolumn{3}{c}{ Percent of uptake in $\mathrm{Na}^{+}$medium } \\
\cline { 2 - 4 } Inhibitor & $\mathrm{Na}^{+}$medium & $\mathrm{Li}^{+}$medium & Choline medium \\
\hline None & $(100)$ & 36 & 39 \\
MeAIB & 74 & $\mathrm{ND}$ & $\mathrm{ND}$ \\
AIB & 36 & $\mathrm{ND}$ & $\mathrm{ND}$ \\
Leucine & 22 & 4 & 0 \\
Serine & 19 & 9 & 7 \\
Histidine & 46 & 4 & 0 \\
\hline
\end{tabular}

CEM cells $\left(2 \times 10^{6} / \mathrm{ml}\right)$ were incubated for $15 \mathrm{~min}$ at $37^{\circ} \mathrm{C}$ with 0.5 $\mathrm{mM}\left[{ }^{14} \mathrm{C}\right]$ glutamine and $5 \mathrm{mM}$ glucose in the presence and absence of $20 \mathrm{mM}$ unlabeled amino acids. Determinations were in triplicate.
Although it is likely that attack on membrane components was responsible for inhibition, inactivation of intracellular enzymes could also result in inhibition of glutamine uptake. Transport systems catalyze the movement of substrates into and out of the cell, but intracellular $\left[{ }^{14} \mathrm{C}\right]$ glutamine was rapidly deaminated to $\mathrm{NH}_{4}^{+}$and labeled products that were not transported out of the cell. The labeled products were also not rapidly metabolized to other products such as ${ }^{14} \mathrm{CO}_{2}$ that could diffuse out of the cell. Therefore, deamination trapped the label in the cell and may have permitted a higher level of intracellular accumulation of label. If the deaminating enzymes were inactivated, intracellular accumulation of label might be inhibited even if membrane transport systems were fully active. To determine whether deaminating enzymes were inhibited, CEM cells were incubated $10 \mathrm{~min}$ at $37^{\circ} \mathrm{C}$ in $\mathrm{Cl}^{-}$ medium, in $\mathrm{Cl}^{-}$medium with $100 \mu \mathrm{M} \mathrm{HOCl}$ to lyse the cells, or in $15 \mathrm{mM}$ phosphate buffer to osmotically lyse the cells. DTT $(0.1 \mathrm{mM})$ was added to reduce any oxidants derived from $\mathrm{HOCl}$, the incubation was continued for $1 \mathrm{~h}$ at $37^{\circ} \mathrm{C}$ with and without $10 \mathrm{mM}$ glutamine, and $\mathrm{NH}_{4}^{+}$production was measured. Glutamine-dependent $\mathrm{NH}_{4}^{+}$production by the $\mathrm{HOCl}$ lysate was only $14 \%$ less than that of intact cells, and osmotic lysis caused a similar small inhibition. Therefore, inhibition of deamination did not account for inhibition of uptake.

\section{Discussion}

Inhibition of CEM cell glutamine uptake was a sensitive indicator of the cytotoxic activity of stimulated neutrophils. Inhibition was observed at low E/T ratios, in short incubation times, and regardless of whether cells were incubated as a suspension or a pellet. The results indicate that stimulated neutrophils are potent antitumor effector cells when cytotoxicity rather than cytolysis is the measure of antitumor activity.

Cytolysis as measured by ${ }^{51} \mathrm{Cr}$ release was observed under a more limited set of conditions. Higher E/T ratios, longer incubations, and incubation of the cells as a pellet were required. Results were also influenced by the total number of cells. The best results were obtained with low numbers of cells spread over a large area to obtain a very thin layer of cells, which may increase opportunities for cell-cell contact. Alternatively, the effect of cell number may be due to depletion of $\mathrm{O}_{2}$ in thick cell layers (52), which would inhibit oxidative mechanisms of toxicity.

The low sensitivity of the ${ }^{51} \mathrm{Cr}$-release assay as compared with the glutamine uptake assay indicates that more extreme conditions are required to break open the target cells than to inhibit target cell functions. Other factors may also contribute to the sensitivity of glutamine uptake to neutrophil toxins. The $N$ and $A S C$ transport systems are inactivated by agents that react with sulfhydryl groups $(51,53)$, suggesting that these systems would be susceptible to oxidative inactivation. Transport systems must also be partially exposed on the cell surface. These membrane components would be accessible to leukocyte toxins and would be subjected to higher levels of toxins than intracellular components, which are protected by the membrane barrier and by high intracellular levels of protective enzymes and reducing agents.

Although inhibition of glutamine uptake was a more sensitive indicator than ${ }^{51} \mathrm{Cr}$ release, the principal mechanism of toxicity was the same regardless of the indicator. MPO-cata- 
lyzed oxidation of $\mathrm{Cl}^{-}$to $\mathrm{HOCl}$ was required for toxicity. The reaction of $\mathrm{HOCl}$ with endogenous $\mathrm{NH}_{4}^{+}$to yield $\mathrm{NH}_{2} \mathrm{Cl}$ and the oxidation of CEM cell components by $\mathrm{NH}_{2} \mathrm{Cl}$ was the probable mechanism of toxicity. However, the high level of endogenous $\mathrm{NH}_{4}^{+}(>50 \mu \mathrm{M})$ made it impossible to demonstrate an effect of added $\mathrm{NH}_{4}^{+}$. Moreover, there was not a great difference in toxicity of $\mathrm{HOCl}$ and $\mathrm{NH}_{2} \mathrm{Cl}$ to CEM cells, perhaps because $\mathrm{HOCl}$ reacted rapidly with $\mathrm{NH}_{4}^{+}$released by the cells. Therefore, it was not possible to distinguish between the toxicity of $\mathrm{HOCl}$ or $\mathrm{NH}_{2} \mathrm{Cl}$, though $\mathrm{NH}_{2} \mathrm{Cl}$ was shown to mediate neutrophil cytotoxicity to erythrocytes (46).

The glutamine uptake assay also revealed a nonoxidative contribution to neutrophil cytotoxicity that was not detected in the ${ }^{51} \mathrm{Cr}$-release assay. This nonoxidative mechanism was observed only when cells were incubated as a pellet, suggesting that close continuous cell-cell contact was required. Failure to detect a nonoxidative contribution to ${ }^{51} \mathrm{Cr}$ release may indicate that this mechanism was cytotoxic but not cytolytic, that longer incubations would be required for cytolysis, or that this mechanism was ineffective at the low cell numbers required for the ${ }^{51} \mathrm{Cr}$-release assay.

The nonoxidative contribution to cytotoxicity was defined as inhibition that could not be blocked by adding catalase, dapsone, or oxidant scavengers such as DTT, taurine, hypotaurine, or thiodipropionate. Exclusion of a large molecule such as catalase from the limited area of cell-cell contact (54) might account for the failure of catalase to completely block toxicity. On the other hand, MPO and SOD are also large, but they were effective in boosting toxicity. Moreover, if the MPO system was responsible for all the toxicity, then dapsone and the small scavenger molecules would have to be physically excluded, while $\mathrm{H}_{2} \mathrm{O}_{2}$ and $\mathrm{Cl}^{-}$were not excluded.

Further studies will be required to determine the basis for inhibition of glutamine uptake. As discussed above, transport systems are likely targets for attack by neutrophil toxins. However, inhibition of a particular transport system could not account for the results. Three transport systems made major contributions to uptake, and neutrophils almost completely inhibited uptake, indicating a general inhibitory effect. Two of the transport systems were $\mathrm{Na}^{+}$dependent, so that loss of the $\mathrm{Na}^{+}, \mathrm{K}^{+}$, and $\mathrm{H}^{+}$gradients across the cell membrane would be sufficient to substantially inhibit uptake. Loss of these gradients could result from increased membrane permeability to monovalent cations, inhibition of the $\mathrm{Na}^{+} / \mathrm{K}^{+}$ATPase pump in the cell membrane, or depletion of ATP.

The results suggest that inhibition of energy metabolism and depletion of ATP were not responsible for inhibition of glutamine uptake. ATP levels remained high in cells inhibited by $\mathrm{NH}_{2} \mathrm{Cl}$ or $\mathrm{HOCl}$. In addition, preincubating CEM cells without glucose did not inhibit glutamine uptake, so that neutrophil inhibition of CEM cell glucose uptake or metabolism would not be sufficient to inhibit glutamine uptake. Prolonged incubations with inhibitors of energy metabolism were required to inhibit uptake. Inhibition of uptake by neutrophils was much faster, suggesting that neutrophil toxins had a direct effect on amino acid transport, the $\mathrm{Na}^{+} / \mathrm{K}^{+}$ATPase, or cation permeability.

Regardless of the basis for inhibition, decreased glutamine transport and metabolism would inhibit growth of cells that require glutamine and might result in cell death if this inhibition were not reversed or overcome. Inhibition of glutamine uptake is probably not specific to tumor cells, but would be more significant for cells that require glutamine, which may include many tumor cells. Therefore, inhibition of glutamine uptake may be not only useful as an indicator of neutrophil cytotoxicity, but may represent a significant tumoristatic or tumoricidal effect.

\section{Acknowledgments}

We gratefully acknowledge the support and encouragement of the late Dr. Martin Morrison.

This research was supported by grants AI-16795 and CA-09346 from the National Institutes of Health and by the American Lebanese Syrian Associated Charities.

\section{References}

1. Edelson, P. J., and Z. A. Cohn. 1973. Peroxidase-mediated mammalian cell cytotoxicity. J. Exp. Med. 138:318-323.

2. Clark, R. A., S. J. Klebanoff, A. B. Einstein, and A. Fefer. 1975. Peroxidase- $\mathrm{H}_{2} \mathrm{O}_{2}$-halide system: cytotoxic effect on mammalian tumor cells. Blood. 45:161-170.

3. Clark, R. A., and S. J. Klebanoff. 1975. Neutrophil-mediated tumor cell cytotoxicity: role of the peroxidase system. J. Exp. Med. 141:1442-1447.

4. Clark, R. A., and S. J. Klebanoff. 1977. Studies on the mechanism of antibody-dependent polymorphonuclear leukocyte-mediated cytotoxicity. J. Immunol. 119:1413-1418.

5. Clark, R. A., and S. J. Klebanoff. 1979. Role of the myeloperoxidase- $\mathrm{H}_{2} \mathrm{O}_{2}$-halide system in conconavalin A-induced tumor cell killing by human neutrophils. J. Immunol. 122:2605-2610.

6. Slivka, A., A. F. LoBuglio, and S. J. Weiss. 1980. A potential role for hypochlorous acid in granulocyte-mediated tumor cell cytotoxicity. Blood. 55:347-350.

7. Clark, R. A., and S. Szot. 1981. The myeloperoxidase-hydrogen peroxide-halide system as effector of neutrophil-mediated tumor cell cytoxicity. J. Immunol. 126:1295-1301.

8. Klassen, D. K., P. R. Conkling, and A. L. Sagone, Jr. 1982. Activation of monocyte and granulocyte antibody-dependent cytotoxicity by phorbol myristate acetate. Infect. Immun. 35:818-825.

9. Weiss, S. J., and A. Slivka. 1982. Monocyte and granulocytemediated tumor cell destruction. A role for the hydrogen peroxidemyeloperoxidase-chloride system. J. Clin. Invest. 69:255-262.

10. English, D., and J. N. Lukens. 1983. Regulation of neutrophil inflammatory mediator release: chemotactic peptide activation of stimulus-dependent cytotoxicity. J. Immunol. 130:850-856.

11. Clark, R. A. 1983. Extracellular effects of the myeloperoxidase-hydrogen peroxide-halide system. Adv. Inflamm. Res. 5:107-146.

12. Grisham, M. B., M. M. Jefferson, D. F. Melton, and E. L. Thomas. 1984. Chlorination of endogenous amines by isolated neutrophils: ammonia-dependent bactericidal, cytotoxic, and cytolytic activities of the chloramines. J. Biol. Chem. 259:10404-10413.

13. Clark, R. A., I. Olsson, and S. J. Klebanoff. 1976. Cytotoxicity for tumor cells of cationic proteins from human neutrophil granules. $J$. Cell Biol. 70:719-723.

14. Lichtenstein, A., T. Ganz, M. E. Selsted, and R. I. Lehrer. 1986. In vitro tumor cell cytolysis mediated by peptide defensins of human and rabbit granulocytes. Blood. 68:1407-1410.

15. Westall, R. G. 1962. The free amino acids of body fluids and some hereditary disorders of amino acid metabolism. In Amino Acids Pools. J. T. Holden, editor. Elsevier/North Holland, Amsterdam. 195-219.

16. Christensen, H. N. 1982. Interorgan amino acid transport. Physiol. Rev. 62:1193-1233.

17. Novogrodsky, A., R. E. Nehring, Jr., and A. Meister. 1979. Inhibition of amino acid transport into lymphoid cells by the glutamine analog L-2-amino-4-oxo-5-chloropentanoate. Proc. Natl. Acad. Sci. USA. 76:4932-4935. 
18. Lund, P. 1980. Glutamine metabolism in the rat. FEBS (Fed. Eur. Biochem. Soc.) Lett. 117(Suppl.):K86-K92.

19. Newsholme, E. A., B. Crabtree, and M. S. Andarwi. 1985. Glutamine metabolism in lymphocytes: its biochemical, physiological, and clinical importance. Q. J. Exp. Physiol. 70:473-489.

20. Ardarwi, M. S., and E. A. Newsholme. 1986. The transport of glutamine into rat mesenteric lymphocytes. Biochim. Biophys. Acta. 856:413-420.

21. Reitzer, L. J., B. M. Wice, and D. Kennel. 1979. Evidence that glutamine, not sugar, is the major energy source for cultured HeLa cells. J. Biol. Chem. 254:2669-2676.

22. Zielke, H. R., C. L. Zielke, and P. T. Ozand. 1984. Glutamine: a major energy source for cultured mammalian cells. Fed. Proc. 43:121-125.

23. Hornsby, P. J. 1982. The role of vitamin E in cellular energy metabolism in cultured adrenocortical cells. J. Cell. Physiol. 112:207216.

24. Abou-Khalil, W. H., A. A. Yunis, and S. Abou-Khalil. 1983. Prominent glutamine oxidation activity in mitochondria of hematopoietic tumors. Cancer Res. 43:1990-1993.

25. Moreadith, R. W., and A. L. Lehringer. 1984. The pathways of glutamate and glutamine oxidation by tumor cell mitochondria. Role of mitochondrial NAD(P) ${ }^{+}$-dependent malic enzyme. J. Biol. Chem. 259:6215-6221.

26. Lazarus, P., and L. C. Panasci. 1986. Characterization of Lthreonine and L-glutamine transport in murine P388 leukemia cells in vitro. Presence of an $\mathrm{N}$-like amino acid transport system. Biochim. Biophys. Acta. 856:488-495.

27. Roberts, J., J. S. Holcenberg, and W. C. Dolowy. 1970. Antineoplastic activity of highly purified bacterial glutaminases. Nature (Lond.). 227:1136-1137.

28. Spiers, A. S., and H. E. Wade. 1979. Achromobacter L-glutaminase-L-asparaginase: human pharmacology, toxicology, and activity in acute leukemias. Cancer Treat. Rep. 63:1019-1024.

29. Rosenfeld, H., and J. Roberts. 1981. Enhancement of antitumor activity of glutamine antagonists 6-diazo-5-oxo-L-norleucine and acivicin in cell culture by glutaminase-asparaginase. Cancer Res. 41:1324-1328.

30. Tannock, I. F., D. Steele, and J. Roberts. 1986. Influence of reduced concentration of L-glutamine on growth and viability of cells in monolayer, in spheroids, and in experimental tumors. Br. J. Cancer. 54:733-741.

31. Rouser, G., K. Kelly, A. J. Samuels, B. Jelinek, and D. Heller. 1962. Free amino acids in the blood of man and animals. II. Normal individuals and patients with chronic granulocytic leukemia and polycythemia. In Amino Acid Pools. J. T. Holden, editor. Elsevier/North Holland, Amsterdam. 373-387.

32. Bakkenist, A. R. J., R. Wever, T. Vulsma, H. Plat, and B. F. Van Gelder. 1978. Isolation procedures and some properties of myeloperoxidase from human leukocytes. Biochim. Biophys. Acta. 524:45-54.

33. Matheson, N. R., P. S. Wong, and J. Travis. 1981. Isolation and properties of human neutrophil myeloperoxidase. Biochemistry. 20:325-330.

34. Thomas, E. L., M. B. Grisham, and M. M. Jefferson. 1986. Preparation and characterization of chloramines. Methods Enzymol. 132:569-585.

35. Thomas, E. L., M. B. Grisham, and M. M. Jefferson. 1986. Cytotoxicity of chloramines. Methods Enzymol. 132:585-593.
36. Foley, G. E., H. Lazarus, S. Farber, B. G. Uzman, B. A. Boone, and R. E. McCarthey. 1965. Continuous culture of human lymphoblasts from peripheral blood of a child with acute leukemia. Cancer (Phila.). 18:522-529.

37. Thomas, E. L., D. B. Learn, M. M. Jefferson, and W. Weatherred. 1988. Superoxide-dependent oxidation of extracellular reducing agents by isolated neutrophils. J. Biol. Chem. 263:2178-2186.

38. Stendahl, O., L. Molin, and C. Dahlgren. 1978. The inhibition of polymorphonuclear leukocyte cytotoxicity by dapsone. A possible mechanism in the treatment of dermatitis herpetiformis. J. Clin. Invest. 62:214-220.

39. Thomas, E. L. 1979. Myeloperoxidase-hydrogen peroxidechloride antimicrobial system: effect of exogenous amines on antibacterial action against Escherichia coli. Infect. Immun. 25:110-116.

40. Thomas, E. L., M. B. Grisham, and M. M. Jefferson. 1983. Myeloperoxidase-dependent effect of amines on functions of isolated neutrophils. J. Clin. Invest. 72:441-454.

41. Thomas, E. L., M. B. Grisham, D. F. Melton, and M. M. Jefferson. 1985. Evidence for a role of taurine in the in vitro oxidative toxicity of neutrophils toward erythrocytes. J. Biol. Chem. 260:33213329.

42. Thomas, E. L., M. M. Jefferson, J. J. Bennett, and D. B. Learn. 1987. Mutagenic activity of chloramines. Mutat. Res. 188:35-43.

43. Thomas, E. L., and M. Fishman. 1986. Oxidation of chloride and thiocyanate by isolated leukocytes. J. Biol. Chem. 261:9694-9702.

44. Rowe, W. B., and A. Meister. 1973. Studies on the inhibition of glutamine synthetase by methionine sulfone. Biochemistry. 12:15781582.

45. Arad, G., and R. G. Kulka. 1978. Effects of glutamine, methionine sulfone and dexamethasone on rates of synthesis of glutamine synthetase in cultured hepatoma cells. Biochim. Biophys. Acta. 554:153-162.

46. Grisham, M. B., M. M. Jefferson, and E. L. Thomas. 1984. Role of monochloramine in the oxidation of erythrocyte hemoglobin by stimulated neutrophils. J. Biol. Chem. 259:6757-6765.

47. Christensen, H. N., M. Liang, and E. G. Archer. 1967. A distinct $\mathrm{Na}^{+}$-requiring transport system for alanine, serine, cysteine, and similar amino acids. J. Biol. Chem. 242:5237-5246.

48. Christensen, H. N. 1985. On the strategy of kinetic discrimination of amino acid transport systems. J. Membr. Biol. 84:97-103.

49. Christensen, H. N., M. E. Handlogten, I. Lam, H. S. Tager, and R. Zand. 1969. A bicyclic amino acid to improve discriminations among transport systems. J. Biol. Chem. 244:1510-1520.

50. Kilberg, M. S., M. E. Handlogten, and H. N. Christensen. 1980. Characteristics of an amino acid transport system in rat liver for glutamine, asparagine, histidine, and closely related analogues. J. Biol. Chem. 255:4011-4019.

51. Vadgama, J. V., and H. N. Christensen. 1983. Comparison of system $\mathrm{N}$ in fetal hepatocytes and in related cell lines. J. Biol. Chem. 258:6422-6429.

52. Thomas, E. L., and M. Fishman. 1982. Hydrogen peroxide release by rat peritoneal macrophages in the presence and absence of tumor cells. Arch. Biochem. Biophys. 215:355-366.

53. Eavenson, E., and H. N. Christensen. 1967. Transport systems for neutral amino acids in the pigeon erythrocyte. J. Biol. Chem. 242:5386-5396.

54. Hafeman, D. G., and Z. J. Lucas. 1979. Polymorphonuclear leukocyte-mediated, antibody-dependent, cellular cytotoxicity against tumor cells: dependence on oxygen and the respiratory burst. J. Immunol. 123:55-62. 